\title{
ANALISIS YURIDIS PERLINDUNGAN KONSUMEN TERHADAP INFORMASI IKLAN YANG MENYESATKAN
}

\section{Rizki Tri Anugrah Bhakti ${ }^{1}$, Padrisan Jamba ${ }^{1}$}

\author{
${ }^{1}$ Dosen Program Studi Ilmu Hukum, Fakultas Ilmu Sosial Dan Humaniora, Universitas \\ Putera Batam, Jl Letjen R. Soeprapto Tembesi-Batu Aji Batam, Kampus UPB, Batam 29433, \\ Indonesia \\ ${ }^{1}$ Penyesuaian Pengarang E-mail: rizki.tri.ab@gmail.com \\ No Hp: +6281332752212 \\ ${ }^{1}$ Penyesuaian Pengarang E-mail: padri_themasterlaw@yahoo.com \\ No Hp: +6282283347554
}

\begin{abstract}
ABSTRAK
Periklanan sebagai salah satu sarana pemasaran dan sarana penerangan memegang peranan penting di dalam pembangunan. Agar produk yang ditawarkan oleh pelaku usaha memiliki nilai jual yang tinggi terkadang pelaku usaha menghalalkan segala cara. Salah satunya dengan melalui iklan yang memuat janji yang muluk-muluk mengenai kegunaan dan manfaat produk yang sesuai dengan kebutuhan konsumen. Perlunya peraturan yang mengatur perlindungan konsumen karena lemahnya posisi konsumen dibandingkan posisi pelaku usaha, karena mengenai proses sampai hasil produksi barang atau jasa yang telah dihasilkan campur tangan konsumen sedikitpun. Mengenai periklanan belum ada peraturan yang mengatur secara khusus, tetapi masalah iklan terdapat dalam beberapa pasal di Undang-Undang Nomor 8 Tahun 1999 tentang Perlindungan Konsumen. Sumber utama penelitian ini adalah data yang sudah tersedia dalam bentuk ketentuan-ketentuan hukum yang sudah pernah ditulis, yang kemudian akan dikaji menurut ketentuan perundang-undangan yang berlaku, sebagaimana pendekatan yang digunakan adalah yuridis normatif yaitu dilakukan dengan cara menelaah dan menginterpretasikan hal-hal yang bersifat teoritis yang menyangkut asas, konsepsi, doktrin dan norma hukum yang berkaitan dengan perlindungan konsumen dan perjanjian. Analisis data dalam penelitian ini menggunakan analisis kualitatif. Berdasarkan hasil analisis ditarik kesimpulan secara dedukatif, yaitu cara berpikir yang didasarkan pada fakta-fakta yang bersifat umum untuk kemudian ditarik suatu kesimpulan bersifat khusus.
\end{abstract}

Kata kunci: Iklan, Konsumen, Pelaku Usaha 


\section{ABSTRACT}

Advertising as one means of marketing and lighting facilities plays an important role in development. In order for products offered by business actors have high selling value sometimes business actors justifies all means. One of them is through advertising that contains a grandiose promise about the usefulness and benefits of products that suit the needs of consumers. The need for regulations that regulate consumer protection because of the weakness of consumer position compared to the position of business actors, because of the process until the production of goods or services that have produced consumer intervention at all. Regarding advertising there is no specific regulatory regulation, but the advertising problem is contained in several articles in Law No. 8 of 1999 on Consumer Protection. The main source of this research is the data already available in the form of legal provisions that have been written, which will then be studied according to the provisions of applicable legislation, as the approach used is normative juridical is done by reviewing and interpreting things theoretical nature of principles, conceptions, doctrines and legal norms relating to consumer protection and covenants. Data analysis in this research using qualitative analysis. Based on the results of the analysis, deductive conclusions are drawn, namely the way of thinking based on general facts and then drawn a specific conclusion.

Key word: Advertising, Consumers, Business Actors

\section{PENDAHULUAN}

\subsection{Latar Belakang Masalah}

Periklanan sebagai salah satu sarana pemasaran dan sarana penerangan memegang peranan penting di dalam pembangunan yang dilaksanakan bangsa Indonesia. Sebagai sarana penerangan dan pemasaran, periklanan merupakan bagian dari kehidupan media komunikasi yang vital bagi pengembangan dunia usaha, serta harus berfungsi menunjang pembangunan (Ahmad Yani, 2008).

Pada dasarnya konsumen pengguna tidak akan mengetahui semua jenis produk barang dan jasa sehingga masyarakat sangat memerlukan informasi produk barang dan jasa apa saja yang ada di pasaran. Untuk menyampaikan informasi tersebut digunakan iklan, baik melalui media cetak maupun elektronik.Di samping sebagai alat informasi baik melalui media cetak maupun elektronik, 
iklan bagi pelaku usaha adalah media yang sangat dibutuhkan untuk memasarkan produknya dan menaikkan jumlah penjualan (Taufik, 2004).

Faktor utama yang menjadi kelemahan konsumen adalah tingkat kesadaran konsumen akan haknya masih rendah. Hal ini terutama disebabkan oleh rendahnya pendidikan konsumen. Oleh karena itu, Undang-undang Perlindungan

Konsumen dimaksudkan menjadi landasan hukum yang kuat bagi pemerintah dan lembaga perlindungan konsumen swadaya masyarakat untuk melakukan upaya pemberdayaan konsumen melalui pembinaan dan pendidikan konsumen.Upaya pemberdayaan ini penting karena tidak mudah mengharapkan kesadaran pelaku usaha yang pada dasarnya prinsip ekonomi pelaku usaha adalah mendapat keuntungan yang semaksimal mungkin dengan modal seminimal mungkin.Prinsip ini sangat potensial merugikan kepentingan konsumen, baik secara langsung maupun tidak langsung.

$$
\text { Apalagi dengan }
$$

perkembangan dan inovasi dalam komputasi dan teknologi telekomunikasi memungkinkan pelaku usaha untuk melakukan berbagai tindakan baik yang menguntungkan maupun merugikan konsumen. Misalnya di bidang kedokteran, dengan adanya jarak geografis yang jauh antara dokter dan pasien memunculkan praktek telemedicine, Praktek ini mnemungkinkan orang-orang di seluruh dunia mendapat pelayanan di bidang kesehatan tanpa bertemu langsung dengan dokter (Daly: 2000).

Secara filosofis, perlindungan konsumen dilakukan untuk menciptakan keseimbangan hak dan kewajiban diantara pelaku usaha dan konsumen, sehingga paradigma uzur let be consumer beware (konsumen yang harus berhati -hati dalam mengkonsumsi barang dan jasa) menjadi paradigma let producer beware (pelaku usaha harus berhati -hati 
sebelum memproduksi dan memperdagangkan barang dan jasa ke pasar).

Secara

sosiologis,

pengaturan

perlindungan

konsumen ditujukan untuk masyarakat sebagai konsumen dan masyarakat sebagai pelaku usaha.Masyarakat sebagai konsumen memiliki arti bahwa, konsumen harus cerdas dan cermat dalam memilih dan menggunakan suatu produk supaya dapat sesuai dengan kebutuhan dan harapan konsumen itu sendiri.

Sebagai salah satu negara di Asia, negara Cina sudah memberlakukan Undang-Undang Perlindungan Konsumen terlebih dahulu yaitu sejak tahun 1993. Undang-Undnag tersebut berfungsi tidak hanya sebagai langkah pertama menuju pembentukan perlindungan konsumenkerangka hukum, untuk tingkat tertentu, juga memperkuat kesadaran hak-hak konsumen (Shigang : 2012). Tentunya hal ini akan menjadi cambuk bagi pemerintah Indonesia untuk juga memiliki tujuan mencerdaskan konsumen agar terhindar dari kerugian akibat iklan yang menyesatkan.

Dengan alasan memperhatikan kelemahan konsumen untuk lebih selektif dalam membeli produk dari iklan yang dilihatnya, hingga berujung pada dirugikannya konsumen karenanya, maka penelitian ini dirasakan sangat menarik dan layak untuk diteliti.

\subsection{Rumusan Masalah}

Berdasarkan latar belakang masalah yang diuraikan diatas, maka rumusan masalah yang akan dikaji dalam penelitian ini adalah sejauhmana Undang-Undang Perlindungan Konsumen dapat mencegah dan mengatasi iklan yang dapat merugikan konsumen?

\section{METODE PENELITIAN}

\subsection{Desain Penelitian}

Dalam melakukan suatu penelitian, para peneliti membutuhkan sebuah metode (desain penelitian) dalam hal ini 
menggunakan penelitian dan atau kualitatif tentunya penelitian tersebut yang akan menyesuaikan kebutuhan suatu penelitian. Sehubungan hal tersebut, dimana draf proposal ini, peneliti menggunakan desain dengan metode kualitatif. Dalam penelitian kualitatif yang bertolak dari data, memaanfaatkan teori yang ada sebagai bahan penjelasan, dan berakhir dengan suatu teori.Atauyang disebut desain penelitian, dalam hal ini menggunakan penelitian biasa menggunakan penelitian yang sifatnya kuantitatif dan atau kualitatif. Dalam kedua bentuk tersebut tentunya penelitian akan pada kemauan dan atau disesuaikan kebutuhan suatu penelitian tersebut.

Menurut Nazir bahwa penelitian adalahsuatu proses mencari sesuatu yang sistematis dalam waktu yang lama dengan menggunakan metode ilmiah serta aturan-aturan yang berlaku. Desain dari penelitian adalah proses yang diperlukan dalam perencanaan penelitian. Dalam pengertian yang sempit, desain penelitian hanya mengenai pengumpulan dan analisis data saja, dan dalam pengertian lebih luas desain penelitian adalah mencakup proses-proses yaitu sebagai berikut:

1. Identifikasi masalah dan penelitian masalah penelitian

2. Pemilihan kerangka konsepsional untuk masalah penelitian serta hubunganhubungan dengan penelitian sebelumnya

3. Memformulasikan masalah penelitian termasuk membuat spesifikasi dan tujuan, luas jangkauan (scope), dan hipotesis untuk diuji

4. Membangun penyelidikan atau percobaan

5. Memilih serta memberikan definisi terhadap pengukuran batas wilayah

6. Memilih prosedur pengamatan secara langsung

7. Menyusun alat serta teknik untuk mengumpulkan data 
8. Menganalisis data serta mengadakan

Pelaporan hasilpenelitian, termasuk proses penelitian, diskusi serta intrerpretasi data, generalisasi, kekurangan-kekurangan dalam penemuan, serta menganjurkan beberapa saran-saran dan kerja penelitian yang akan dating (Nazir, 2011).

Sehubungan hal tersebut diatas, Peneliti dalam menyusun dan atau melakukan penelitian ini, peneliti nantinya akan menggunakan desain dengan metode kualitatif. Dalam penelitian kualitatif bertolak dari data yang ada memanfaatkan teori yang ada sebagai bahan penjelasan dan berakhir dengan suatu teori.

III. HASIL PEMBAHASAN

Undang-Undang Perlindungan

Konsumen dapat Mencegah dan

Mengatasi Iklan yang dapat Merugikan Konsumen

Saat ini perkembangan komunikasi dan informasi berjalan sangat pesat sejalan dengan laju pembangunan di segala bidang. Hal tersebut menuntut suatu gerak manusia yang cepat, efisien, dan mudah agar segala kebutuhan dapat segera terpenuhi. Globalisasi informasi dalam bidang politik, ekonomi, sosial dan budaya berkembang dengan baik karena cepatnya jaringan informasi. Hal ini juga berkorelasi dengan pesatnya pembangunan disegala bidang yang mendorong meningkatnya mobilitas gerak manusia yang cepat dan dinamis sehingga meminta penyampaian informasi yang cepat dan dinamis pula.

Pesatnya pembangunan salah satunya adalah di bidang ekonomi dan hal tersebut tidak akan lepas dari adanya aktivitas promosi atau biasa disebut dengan periklanan. Tanpa periklanan, berbagai produk tidak akan dapat mengalir ke para distributor atau penjual apalagi ke konsumen (Ani Wijayanti Suhartono, 2004). Inilahyang kemudian memberikan pengaruh terhadap pertumbuhan 
perekonomian nasional sehingga dapat meningkatkan pertumbuhan dunia usaha yang memiliki kemampuan dalam menghasilkan barang dan jasa untuk meningkatkan kesejahteraan masyarakat tanpa mengakibatkan kerugian konsumen. Hal ini karena Peningkatan kesejahteraan masyarakat tanpa mengakibatkan kerugian konsumen memiliki arti adanya kepastian atas mutu, jumlah, dan keamanan barang dan jasa yang didapatkan di pasar oleh masyarakat sebagai konsumen

\section{Istilah "konsumen"} berdasarkan Undang-Undang Nomor 8 Tahun 1999 tentang Perlindungan Konsumen diartikan sebagai "Setiap orang pemakai barang dan/atau jasa yang tersedia dalam masyarakat, baik bagi kepentingan diri sendiri, keluarga, orang lain, maupun makhluk hidup lain dan tidak untuk diperdagangkan", sedangkan perlindungan konsumen diartikan sebagai "Segala upaya yang menjamin adanya kepastian hukum

untuk

memberi

perlindungan kepada konsumen".

Barang yang digunakan oleh konsumen dapat diartikan sebagai "Setiap benda baik berwujud maupun tidak berwujud, baik bergerak maupun tidak bergerak, dapat dihabiskan maupun tidak dapat dihabiskan yang dapat untuk diperdagangkan, dipakai, dipergunakan atau dimanfaatkan oleh konsumen", sedangkan jasa yang digunakan oleh konsumen diartikan sebagai "setiap layanan yang berbentuk pekerjaan atau prestasi yang disediakan bagi masyarakat untuk dimanfaatkan oleh konsumen".

Konsumen membutuhkan sebuah perlindungan, tentunya perlindungan konsumen tersebut dilakukan untuk menciptakan keseimbangan hak dan kewajiban diantara pelaku usaha dan konsumen, sehingga paradigma uzur let be consumer beware (konsumen yang harus berhati hati dalam mengkonsumsi barang dan jasa) menjadi paradigma let producer beware (pelaku usaha 
harus berhati -hati sebelum memproduksi

dan memperdagangkan barang dan jasa ke pasar).

Iklan yang merupakan sarana informasi bagi pelaku usaha dalam memasarkan produk yang dimiliki telah memberikan dampak negatif terhadap konsumen. Pelaku usaha dengan sengaja menciptakan iklan dengan beragam cara untuk menarik minat konsumen dalam membeli dan menggunakan produk yang ditawarkan. Dalam usaha menarik minat konsumen, pelaku usaha sering menciptakan iklan-iklan yang menyesatkan dan merugikan konsumen.

Perlindungan terhadap konsumen dihubungkan dengan iklan-iklan yang menyesatkan belum mendapatkan penanganan yang optimal di dalam praktik (Widijowati, 2016).

Pengaruh iklan terhadap orang yang melihat, secara umum dapat menambah pengetahuan dan memberikan informasi, sedangkan secara khusus setelah melihat tayangan iklan tersebut diharapkan secara langsung dapat terpengaruh sehingga dapat mengerti isi pesan yang terdapat pada iklan tersebut, dan akhirnya dapat memberikan respon yang positif karena seringnya iklan tersebut ditayangkan (Sri, 2013). Namun tentu saja informasi tersebut harus tetap memberikan rasa aman kepada konsumennya. Secara sosiologis, pengaturan perlindungan konsumen ditujukan untuk masyarakat sebagai konsumen dan masyarakat sebagai pelaku usaha. Masyarakat sebagai konsumen memiliki arti bahwa, konsumen harus cerdas dan cermat dalam memilih dan menggunakan suatu produk supaya dapat sesuai dengan kebutuhan dan harapan konsumen itu sendiri. Masyarakat sebagai pelaku usaha memiliki arti bahwa, pelaku usaha harus selalu berhati-hati dalam merancang, memproduksi, mendistribusikan dan mempromosikan setiap produk yang dimilikinya.

Hukum perlindungan konsumen merupakan bagian dari hukum konsumen yang memuat 
asas-asas atau kaidah-kaidah yang memiliki sifat mengatur dan melindungi kepentingan konsumen. Hukum konsumen adalah hukum yang mengatur hubungan dan masalah antara berbagai pihak satu sama lain berkaitan dengan barang atau jasa konsumen di dalam pergaulan hidup.

Hukum konsumen dan hukum perlindungan konsumen pada prinsipnya memiliki tujuan untuk meningkatkan kesadaran, kemampuan dan kemandirian konsumen untuk melindungi diri, selain memiliki tujuan untuk:

1. Mengangkat harkat dan martabat konsumen dengan cara menghindarkannya dari ekses negatif pemakaian produk.

2. Meningkatkan pemberdayaan konsumen dalam memilih, menentukan dan menuntut hakhaknya sebagai konsumen.

3. Menciptakan sistem perlindungan konsumen yang mengandung unsur kepastian hukum dan keterbukaan informasi serta akses untuk mendapatkan informasi.

4. Menumbuhkan kesadaran pelaku usaha mengenai pentingnya perlindungan konsumen, sehingga tumbuh sikap yang jujur dan bertanggungjawab dalam berusaha.

5. Meningkatkan kualitas produk yang menjamin kelangsungan usaha produksi produk, kesehatan, kenyamanan, keamanan dan keselamatan konsumen.

Eksistensi Undang-Undang Perlindungan Konsumen ditujukan untuk memberikan perlindungan terhadap hak-hak konsumen yang melakukan transaksi produk dengan pelaku usaha tanpa menghilangkan hak-hak yang dimiliki oleh pelaku usaha dan sejumlah kewajiban yang harus dilakukan oleh konsumen, baik sebelum dan setelah menggunakan produk.

Undang-Undang Perlindungan Konsumen diharapkan dapat menjadi titik keseimbangan di antara konsumen 
dan pelaku usaha, karena konsumen dan pelaku usaha memiliki hubungan (interaksi) yang saling mempengaruhi dan menguntungkan

(simbiosis mutualisme).

Mengkaji iklan-iklan yang menyesatkan dan menjebak konsumen dalam praktik, sebenarnya eksistensi iklan telah diatur dalam Pasal 8 ayat (1) huruf f Undang-Undang Perlindungan Konsumen yang menjelaskan bahwa, pelaku usaha dilarang untuk memproduksi atau memperdagangkan produk yang tidak sesuai dengan janji yang dinyatakan dalam label, etiket, keterangan, iklan atau promosi penjualan produk. Sebagaimana pelaku usaha seharusnya memperhatikan hal-hal yang diiklankan tersebut bertentangan dengan kepatutan masyarakat umum aturan kode iklan, misalnya mengiklankan hal yang tidak sesuai dengan realitas masalah yang jelas maka hal tersebut tentu merugikan sisi konsumen (Herawati, 2006).
Upaya untuk mencegah dan mengatasi iklan-iklan yang bermasalah bagi konsumen, sebenarnya Undang-Undang Perlindungan Konsumen secara deskriptif telah mengatur karakteristik-karakteristik iklan yang dilarang, yaitu :

1. Iklan produk yang seolah-olah telah memenuhi dan/atau memiliki potongan harga, harga khusus, standar mutu tertentu, gaya atau mode tertentu, karakteristik tertentu, sejarah atau guna tertentu.

2. Iklan produk yang seolah-olah dalam keadaan baik dan/atau baru.

3. Iklan produk yang seolah-olah telah mendapatkan dan memiliki sponsor, persetujuan, perlengkapan tertentu, keuntungan tertentu, ciri-ciri kerja atau aksesori tertentu.

4. Iklan produk yang seolah-olah dibuat oleh perusahaan yang mempunyai sponsor, persetujuan atau afiliasi.

5. Iklan produk yang seolah-olah tersedia. 
6. Iklan produk yang seolah-olah tidak mengandung cacat tersembunyi.

7. Iklan produk yang seolah-olah merupakan kelengkapan dari barang tertentu.

8. Iklan produk yang seolah-olah berasal dari daerah tertentu.

9. Iklan produk yang seolah-olah secara langsung atau tidak langsung merendahkan produk lain.

10. Iklan produk yang seolah-olah menggunakan kata-kata yang berlebihan, seperti aman, tidak berbahaya, tidak mengandung risiko atau efek sampingan tanpa keterangan yang lengkap.

11. Iklan produk yang seolah-olah menawarkan sesuatu yang mengandung janji yang belum pasti.

Jika menghubungkan dengan aturan hukum yang lain, misalnya berdasarkan Undang-Undang Nomor 40 Tahun 1999 tentang Pers (Selanjutnya cukup disebut sebagai Undang-Undang Pers) perusahaan iklan dilarang membuat dan mengiklankan:
1. Iklan yang berisi merendahkan martabat suatu agama, mengganggu kerukunan hidup antar umat beragama dan bertentangan dengan rasa kesusilaan masyarakat.

2. Iklan yang berisi tentang minuman keras, narkotika, psikotropika dan zat aditif lainnya.

3. Iklan yang berisi peragaan wujud rokok dan penggunaan rokok.

Iklan-iklan yang disiarkan wajib memenuhi persyaratan yang telah dikeluarkan oleh KPI dan iklan yang disiarkan sepenuhnya menjadi tanggung jawab lembaga penyiaran. Lembaga penyiaran yang merupakan bagian dari pelaku usaha dalam UndangUndang Penyiaran juga telah diberikan batasan-batasan yang jelas dalam melakukan siaran iklan, yaitu:

1. Iklan yang dihubungkan dengan ajaran suatu agama, ideologi, pribadi dan/atau kelompok yang menyinggung perasaan atau merendahkan martabat 
agama lain, ideologi lain, pribadi lain, atau kelompok lain.

2. Iklan minuman keras atau sejenisnya dan bahan atau zat adiktif.

3. Iklan rokok yang memperagakan wujud rokok.

4. Iklan yang bertentangan dengan kesusilaan masyarakat dan nilai-nilai agama.

5. Iklan yang berisi eksploitasi anak di bawah umur 18 tahun.

Mengkaji perlindungan konsumen dihadapkan dengan iklan-iklan yang dianggap menyesatkan konsumen harus dapat dipandang berdasarkan hubungan sebab akibat (kausalitas) secara subjektif dan objektif, baik dari sisi konsumen maupun dari sisi pelaku usaha.

1. Kausalitas Subjektif

Konsumen.

Kausalitas subjektif konsumen memiliki arti bahwa, pengkajian harus dilakukan terhadap cara penggunaan konsumen pada suatu produk dihubungkan dengan iklan yang ditawarkan oleh pelaku usaha.

Contoh: Iklan penghematan konsumsi bahan bakar pada suatu produk kendaraan sangat dipengaruhi oleh cara konsumen menggunakan produk tersebut, selain dipengaruhi kualitas kepadatan jalan yang dilalui oleh konsumen.

2. Kausalitas Objektif Konsumen. Kausalitas objektif konsumen memiliki arti bahwa, pengkajian telah dilakukan berdasarkan metode tertentu yang dibandingkan dengan metode yang digunakan oleh pelaku usaha sebagai dasar janji iklan. Contoh: Konsumen dan pelaku usaha menggunakan metode kecepatan tetap dikalikan dengan simulasi jarak yang akan ditempuh oleh suatu produk kendaraan, memiliki konsumsi bahan bakar yang sama atau berbeda. Konsumsi bahan bakar yang berbeda antara pengujian yang dilakukan oleh konsumen dan janji pelaku usaha dalam 
iklannya dapat disimpulkan bahwa, iklan yang diberikan oleh pelaku usaha tersebut memiliki unsur yang menyesatkan.

3. Kausalitas Subjektif Pelaku Usaha.

Kausalitas subjektif pelaku usaha memiliki arti bahwa, pengkajian yang dilakukan oleh pelaku usaha terhadap suatu produk hanya didasarkan atas sebagian kualitas produk terbaik tanpa mempertimbangkan faktorfaktor yang mempengaruhi nilai suatu kualitas produk. Contoh: Pelaku usaha mengiklankan suatu produk kendaraan dengan hasil pengkajian konsumsi bahan bakar 1 liter untuk 25 KM tanpa memperhatikan kualitas jalan, kualitas kepadatan jalan, kualitas geografis yang dilalui dan cara mengendarai produk kendaraan tersebut. Pelaku usaha hanya mengambil hasil kualitas nilai tertinggi sebagai dasar iklan tanpa melakukan pengujian berkali-kali dengan metode tertentu dan tanpa memperhatikan faktor-faktor yang mempengaruhi.

4. Kausalitas Objektif Pelaku Usaha.

Kausalitas objektif pelaku usaha memiliki arti bahwa, janji produk yang terdapat pada iklan yang dibuat oleh pelaku usaha telah didasarkan atas metode tertentu dengan mempertimbangkan beragam faktor yang dapat mempengaruhi nilai kualitas suatu produk. Iklan yang ditampilkan menerangkan metode dan faktor yang mempengaruhi untuk mencapai nilai optimal suatu kuallitas produk yang dijanjikan. Contoh: Iklan produk kendaraan yang menjanjikan konsumsi bahan bakar sebesar 1 Liter untuk $25 \mathrm{KM}$ berlaku jika dilakukan dengan kecepatan tertentu, RPM tertentu, Mode tertentu dan kemiringan jalan tertentu berdasarkan nilai kuantitatif tertentu. 
IV. KESIMPULAN SARAN

\subsection{Kesimpulan}

Dari pembahasan yang telah dikemukakan tersebut di atas, dapat ditarik beberapa kesimpulan dalam penelitian ini yaitu bentuk perlindungan hukum yang dapat diberikan terhadap konsumen atas iklan yang menyesatkan dalam UUPK, yaitu dengan adanya pengaturan dalam Bab III Pasal 4 sampai dengan Pasal 7 mengenai hak dan kewajiban pelaku usaha dan kosumen, adanya laranganlarangan bagi pelaku usaha dalam mengiklankan produknya yang terdapat dalam Pasal 9, Pasal 10, Pasal 12, Pasal 13 dan Pasal 17. Bentuk lainnya dengan dibentuknya Badan Perlindungan Konsumen Nasional (BPKN) yang diatur pada Bab VIII UUPK dari Pasal 31 sampai Pasal 43.

\subsection{Saran}

Adapun saran yang disampaikan dalam penelitian ini adalah sebagai berikut:
Hendaknya masyarakat lebih berhati-hati terhadap iklan. Perlu adanya penelaahan secara bijak mengenai kebenaran iklan tersebut. Bagi pemerintah agar dilakukan pembuatan aturan secara khusus mengenai periklanan yang menyesatkan ini. Bagi pelaku usaha agar jujur untuk menawarkan iklan-iklam produk yang akan dipasarkan kepada masyarakat dengan menghindari perbuatan curang. Adapun bagi aparat penegak hukum diharapkan dapat melaksanakan ketentuan sanksi yang ada di dalam Undangundang tersebut secara optimal sehingga hak konsumen dapat dipenuhi dan diperhatikan oleh pelaku usaha di dalam hubungannya antara konsumen dan produsen.

DAFTAR PUSTAKA

Buku-Buku, Jurnal Dan Makalah

Abdul Halim Barkatulah, 2008. Hukum Perlindungan Konsumen (Kajian Teoretis dan 
Perkembangan

Pemikiran,

Nusa Media, Bandung

Ahmad Yani. 2008. Tata Krama dan Tata Cara Periklanan Indonesia.PT.

Gramedia

Pustaka Utama. Jakarta

Ani Wijayanti Suhartono. (2004). Pentingnya Perilaku Konsumen Dalam Menciptakan Iklan Yang Efektif. Nirmana, 6(2). Retrieved from http://puslit2.petra.ac.id/ejourna 1/index.php/dkv/article/view/16 335

Dedi Harianto, 2004. Perlindungan Hukum bagi Konsumen Terhadap Iklan yang Menyesatkan, Ghalia, Bogor

Daly, H. L. (2000). Telemedicine: the invisible legal barriers to the health care of the future. Annals of Health Law / Loyola University Chicago, School of Law, Institute for Health Law, 9,73-106, inside cover.

Herawati, N. (2006). Tanggung Jawab Pelaku Usaha Atas Iklan Yang Menyesatkan. Perspektif, 11(4), 380-389.

Janus $\quad$ Sidabalok. 2006. Perlindungan Konsumen di Indonesia. PT. Citra Aditya Bakti. Bandung
LI Shigang. 2012. The problems of China's Consumer Protection Law in The Legal Practice. International Journal of Business and Sosial Science. Volume 3 Nomor 14

Nazir, M. 2005. Metode Penelitian. Jakarta: Ghalia Indonesia.

Sri, H. (2013). Efektivitas Iklan Layanan Masyarakat Di Televisi. Ilmu Komunikasi, 2 No 2, 1-82.

Taufik H.Simatupang. 2004. Aspek Hukum Periklanan Perspektif Perlindungan. PT. Citra Bakti, Bandung.

Widijowati, D. (2016). Peredaran Iklan yang Menyesatkan Konsumen dihubungkan dengan Hukum Perlindungan Konsumen, Pers dan Penyiaran. Ius Constitutum, 1(2). Retrieved from http://journal.uta45jakarta.ac.id/ index.php/IUSCONS/article/vie $\mathrm{w} / 139 / 231$

Kitab Undang-undang Hukum Perdata (BW)

Kitab Undang-Undang Hukum Pidana

Undang-undang Nomor 8 Tahun 1999 tentang Perlindungan Konsumen 
Undang-Undang Nomor 40 Tahun 1999 tentang Pers. 